Research article

Open Access

\title{
Complexity in Estimation of Esomeprazole and its Related Impurities' Stability in Various Stress Conditions in Low-Dose Aspirin and Esomeprazole Magnesium Capsules
}

\author{
Palavai Sripal RedDY ${ }^{* 1,2}$, Kishore Kumar HothA $^{1}$, Shakil SAIT ${ }^{1}$ \\ ${ }^{1}$ Analytical Research and Development, IPDO, Dr. Reddy's. Ltd. Hyderabad, 500072, India. \\ 2 JNT University, Kukatpally, Hyderabad, 500085, A.P, India. \\ * Corresponding author. E-mail: sripalrp@drreddys.com (P. S. Reddy) \\ Sci Pharm. 2013; 81: 475-492 \\ doi:10.3797/scipharm.1212-13 \\ Published: $\quad$ February $18^{\text {th }} 2013$ \\ Accepted: $\quad$ February $18^{\text {th }} 2013$ \\ Received: $\quad$ December $13^{\text {th }} 2012$
}

This article is available from: http://dx.doi.org/10.3797/scipharm.1212-13

(C) Reddy et al.; licensee Österreichische Apotheker-Verlagsgesellschaft m. b. H., Vienna, Austria.

This is an Open Access article distributed under the terms of the Creative Commons Attribution License (http://creativecommons.org/licenses/by/3.0/), which permits unrestricted use, distribution, and reproduction in any medium, provided the original work is properly cited.

\begin{abstract}
A complex, sensitive, and precise high-performance liquid chromatographic method for the profiling of impurities of esomeprazole in low-dose aspirin and esomeprazole capsules has been developed, validated, and used for the determination of impurities in pharmaceutical products. Esomeprazole and its related impurities' development in the presence of aspirin was traditionally difficult due to aspirin's sensitivity to basic conditions and esomeprazole's sensitivity to acidic conditions. When aspirin is under basic, humid, and extreme temperature conditions, it produces salicylic acid and acetic acid moieties. These two byproducts create an acidic environment for the esomeprazole. Due to the volatility and migration phenomenon of the produced acetic acid and salicylic acid from aspirin in the capsule dosage form, esomeprazole's purity, stability, and quantification are affected. The objective of the present research work was to develop a gradient reversed-phase liquid chromatographic method to separate all the degradation products and process-related impurities from the main peak. The impurities were well-separated on a RP8 column (150 $\mathrm{mm} \mathrm{x}$ $4.6 \mathrm{~mm}, \mathrm{X}$-terra, RP8, 3.5 $\mu \mathrm{m}$ ) by the gradient program using a glycine buffer $(0.08 \mathrm{M}, \mathrm{pH}$ adjusted to 9.0 with $50 \% \mathrm{NaOH})$, acetonitrile, and methanol at a

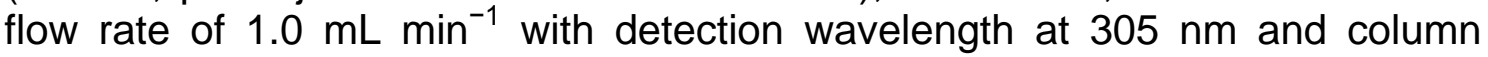
temperature at $30^{\circ} \mathrm{C}$. The developed method was found to be specific, precise, linear, accurate, rugged, and robust. LOQ values for all of the known impurities were below reporting thresholds. The drug was subjected to stress conditions of
\end{abstract}


hydrolysis, oxidation, photolysis, and thermal degradation in the presence of aspirin. The developed RP-HPLC method was validated according to the present $\mathrm{ICH}$ guidelines for specificity, linearity, accuracy, precision, limit of detection, limit of quantification, ruggedness, and robustness.

\section{Keywords}

RP-HPLC • Forced degradation • Validation - Esomeprazole • Aspirin • Acetylsalicylic acid - Method development $\bullet$ Method validation • Degradants $\bullet$ Mmigration

\section{Introduction}

Esomeprazole (Figure 1) is a proton pump inhibitor used in the treatment of dyspepsia, peptic ulcer disease (PUD), gastroesophageal reflux disease (GORD/GERD), and Zollinger-Ellison syndrome. Esomeprazole, the S-enantiomer of omeprazole, shows improved efficacy of this single enantiomer product over the racemic mixture of omeprazole. Esomeprazole is a proton pump inhibitor, which reduces acid secretion through the inhibition of ATPase in gastric parietal cells, by inhibiting the functioning of this enzyme, so the drug prevents formation of gastric acid. The primary uses of esomeprazole are for gastroesophageal reflux disease, treatment of duodenal ulcers caused by $\mathrm{H}$. pylori, prevention of gastric ulcers in those on chronic NSAID therapy, and treatment of gastrointestinal ulcers associated with Crohn's disease [1-3]. In vivo investigations demonstrated that ESO is chirally stable after administration. ESO is $97 \%$ bound to plasma proteins. Omeprazole is a racemic composition of its two optical isomers, S-omeprazole (esomeprazole) and R-omeprazole, which have demonstrated stereoselective metabolisms [4-6]. Aspirin (ASP), also known as acetylsalicylic acid, is a salicylate drug, often used as an analgesic to relieve minor aches and pains, as an antipyretic to reduce fever, and as an anti-inflammatory medication. Aspirin, by irreversibly acetylating cyclo-oxygenase (COX), reduces the production of thromboxane A2 (TXA2) in platelets and prevents platelet aggregation [7]. Aspirin can also reduce prostacyclin (PGI2) production in endothelial cells and cause vasoconstriction. One of the side effects associated with the use of aspirin is gastrointestinal ulcers. Aspirin has a long history of therapeutic use, not only for its analgesic, antipyretic, and anti-inflammatory properties, but also for its anti-thrombotic properties, which are of value in states of platelet hyperaggregability. Aspirin binds irreversibly to the enzyme cyclo-oxygenase-1 (COX-1) in platelets, leading to its antiplatelet effect [8]. Side effects of aspirin treatment are mainly dyspeptic symptoms, gastrointestinal (GI) lesions, and increased gastrointestinal and overall bleeding, which are consequences of the blockage of prostaglandin synthesis through inhibition of various COX enzymes. This leads to a decrease in mucosal protection, which in turn predisposes the patient to mucosal lesions such as peptic ulcers and peptic ulcer bleeding. Esomeprazole is a proton pump inhibitor (PPI) which is indicated, amongst other indications, for the prevention of gastric and duodenal ulcers associated with NSAID therapy (including aspirin therapy). There are many drug products containing aspirin at $100 \mathrm{mg}$ strength as enteric-coated tablets. These are the only lowdose aspirin monotherapy drug products apart from breaking a $300 \mathrm{mg}$ tablet in half, which is probably done by a small proportion of patients taking low-dose aspirin for cardiovascular protection [9-11]. 
<smiles>COc1ccc2[nH]c(S(=O)Cc3ncc(C)c(OC)c3C)nc2c1</smiles>

Esomeprazole<smiles>COc1ccc2[nH]c(SCc3ncc(C)c(OC)c3C)nc2c1</smiles>

Impurity-C (Sulphide impurity)<smiles>COc1ccc2[nH]c(S(=O)Cc3[nH]cc(C)c(=O)c3C)nc2c1</smiles>
Impurity-G (Dihydropyridine impurity)<smiles>COc1ccc2[nH]c(S)nc2c1</smiles>

Impurity-A (Benzimidazole impurity)<smiles>COc1ccc2[nH]c(S(=O)Cc3ncc(C)cc3C)nc2c1</smiles>

Impurity-B (Desmethoxy impurity)<smiles>COc1ccc2[nH]c(S(=O)(=O)Cc3ncc(C)c(OC)c3C)nc2c1</smiles>

Impurity-D (Sulphone impurity)<smiles>COc1c(C)cnc(CS(=O)c2nc3c(OC)cccc3n2C)c1C</smiles>

Impurity-F (N-Methyl impurity)<smiles>COc1ccc2[nH]c(S(=O)Cc3c(C)c(OC)c(C)c[n+]3[O-])nc2c1</smiles>

Impurity-E (N-Oxide impurity)<smiles>O=C(O)c1ccccc1O</smiles>

Salicylic acid

Fig. 1. Chemical Structures of Esomeprazole and its Related impurities

A combination of the esomeprazole and aspirin assay/related impurities method was traditionally difficult due to these drugs' stability in aqueous solutions, dosage variations, and their absorption differences in the UV region. The literature reveals that aspirin is stable in acidic form, whereas esomeprazole is stabile in basic solutions. The objective of the present research work is to establish the specificity and stability of esomeprazole in the presence of aspirin and its related impurities, which gives a precise and accurate quantification of esomeprazole in the pharmaceutical dosage forms of esomeprazole and aspirin. Several HPLC [12-16] and LC-MS/MS [17-29] methods have been reported for the estimation of omeprazole alone or along with its metabolites and in some combination with NSAID in various pharmaceutical dosage forms and in biological fluids. The current research article provides a fully validated and stability-indicating method as per the $\mathrm{ICH}$ guidelines and its degradation behavior in the presence of aspirin and its potential metabolite salicylic acid. The present research article successfully measured the migration content of salicylic acid in the combined capsule dosage form and showed a reliable, accurate quantification of esomeprazole and its related impurities in the presence of aspirin and its potential degradants.

\section{Materials and Methods}

\section{Chemicals and reagents}


Samples of esomeprazole, aspirin and its impurities' standards with purities of $99.8 \%$ were supplied from Dr. Reddy's laboratories Ltd, Hyderabad, India (Figure 1). The HPLC grade acetonitrile, ethanol, methanol, analytical grade glycine, triethylamine, sodium hydroxide, disodium tetraborate decahydrate, and edetate disodium were purchased from Merck, Darmstadt, Germany. High-purity water was prepared by using the Millipore Milli-Q water purification system.

\section{Equipment}

The HPLC system, used for method development, forced degradation studies, and method validation, was a Waters HPLC system equipped with a photodiode array detector, from Waters Corp. (Milford, MA, USA). The output signal was monitored and processed using Empower software (Waters). A water bath equipped with a temperature controller was used to carry out the degradation studies for all solutions. Photostability studies were carried out in a photostability chamber and thermal stability studies were performed in a dry air oven (Mack Phar-ManTech, Hyderabad, India).

\section{Chromatographic Conditions}

The chromatographic column used was a Waters X-Terra RP 8 Column $150 \mathrm{~mm} \times 4.6 \mathrm{~mm}$, $3.5 \mu \mathrm{m}$, all obtained from Waters Corp. (Milford, MA, USA). The gradient LC method consisted of a glycine $(0.08 \mathrm{M})$ buffer $\mathrm{pH} 9.0$ as mobile phase-A, and acetonitrile and methanol in a ratio of $85 / 15 \mathrm{v} / \mathrm{v}$ as mobile phase-B. The flow rate of the mobile phase was $1.0 \mathrm{ml} / \mathrm{min}$ with a gradient programme of $0.001 / 06,12 / 12,17 / 18,17.5 / 20,30 / 40,40 / 46$, $43 / 85,45 / 06,50 / 06$. The column temperature was maintained at $30^{\circ} \mathrm{C}$ and the detection was monitored at a wavelength of $305 \mathrm{~nm}$. The injection volume was $20 \mu$. The diluent used was in a ratio of $80: 20$ (7.6g of disodium tetraborate and $1.0 \mathrm{~g}$ of edetate disodium in 1 liter of Milli-Q water, pH-adjusted to 11.0 with a $50 \%$ sodium hydroxide solution): ethanol.

\section{Preparation of Solutions}

The diluent used for the standard and sample preparation was a mixture of ethanol and disodium tetraborate buffer in the ratio of 80:20 (v/v).

A standard solution of esomeprazole (0.8 ppm), salicylic acid (0.6ppm), and test preparation (400 ppm) was prepared by dissolving an appropriate amount in the diluent.

\section{Specificity}

Specificity is the ability of the method to measure the analyte response in the presence of its potential impurities [30-32]. Stress testing of the drug impurities can help identify the likely degradation products, which can in turn help establish the degradation pathways and the intrinsic stability of the molecule, and validate the stability-indicating power of the analytical procedures used.

The specificity of the developed LC method for esomeprazole was determined in the presence of its related impurities and in the presence of salicylic acid. Forced degradation studies were also performed on esomeprazole to provide an indication of the stabilityindicating property and specificity of the proposed method. The stress conditions employed for the degradation study included light (carried out as per ICH Q1B), dry heating done at $105^{\circ} \mathrm{C}$ for about $2 \mathrm{hrs}$, , acid hydrolysis (refluxed with $0.1 \mathrm{~N} \mathrm{HCl}$ solution for 
about 120 minutes at $60^{\circ} \mathrm{C}$ ), base hydrolysis (refluxed with $0.1 \mathrm{~N} \mathrm{NaOH}$ solution for about 120 minutes at $60^{\circ} \mathrm{C}$ ), water hydrolysis, and oxidation (treated with $3 \%$ hydrogen peroxide $\left(\mathrm{H}_{2} \mathrm{O}_{2}\right)$ for about 120 minutes at RT). Sunlight, thermal, and UV degradation were also performed and the purity of the stressed samples was checked by using a photodiode array detector (PDA). The purity factor was within the threshold limit obtained in all stressed samples, which demonstrates analyte peak homogeneity. The specificity of esomeprazole was shown by spiking all esomeprazole and its related impurities at the specification level (i.e. $0.5 \%$ of analyte concentration, which is $0.2 \mathrm{mg} / \mathrm{mL}$ ).

\section{Analytical method validation}

The developed chromatographic method was validated for linearity, precision, accuracy, sensitivity, robustness, and system suitability as per ICH guidelines [31-33].

\section{Precision}

The precision of the test method was evaluated by analyzing six test samples of low-dose aspirin and esomeprazole capsules. It was spiked with its seven impurities and with the salicylic acid impurity at $0.5 \%$, and then analyzed. The \% RSD of the area of each impurity was calculated.

\section{Limit of detection (LOD) and limit of quantification (LOQ)}

The limit of detection and limit of quantification were established based on the signal-tonoise ratio. A series of solutions having esomeprazole and its related impurities were injected. The limit of detection for the impurity was established by identifying the concentration which gives a signal-to-noise ratio of about 3. The limit of quantification was established by identifying the concentration which gives a signal-to-noise ratio of about 10 . The precision of esomeprazole impurities at about the limit of quantification level was conducted. Six test preparations having impurities at the level of about the limit of quantification were prepared and injected into the HPLC system.

\section{Linearity and Range}

The linearity for esomeprazole and its related impurities was prepared from the limit of quantification level to $150 \%$ of the target concentration $(0.5 \%)$. The linearity was established for salicylic acid from the limit of quantification level to $150 \%$ of the target concentration (0.3\%) and injected into the HPLC system.

\section{Accuracy}

The accuracy of esomeprazole, its related impurities, and salicylic acid was prepared at about the limit of quantification to $150 \%$ of the target concentration level. Test solutions spiked with esomeprazole impurities at about the limit of quantification to $150 \%$ of the target concentration were prepared in triplicate and injected into HPLC system.

\section{Robustness}

To determine the robustness of the developed method, experimental conditions were deliberately changed and the resolution (Rs) between esomeprazole and its impurity was evaluated. The flow rate of the mobile phase was $1.0 \mathrm{~mL} \cdot \mathrm{min}^{-1}$. To study the effect of flow rate on the developed method, 0.2 units of flow was changed (i.e. 0.8 and $1.2 \mathrm{~mL} \cdot \mathrm{min}^{-1}$ ). 
The effect of column temperature on the developed method was studied at $25^{\circ} \mathrm{C}$ and $35^{\circ} \mathrm{C}$ instead of $30^{\circ} \mathrm{C}$. In all of the above-varied conditions, the components of the mobile phase were held constant, and it was established that the allowable variation in $\mathrm{pH}$ of the buffer in the mobile phase was from $\mathrm{pH} 8.8$ to $\mathrm{pH} 9.2$ instead of 9.0.

\section{Solution Stability and Mobile Phase Stability}

The solution stability of esomeprazole, its related impurities, and salicylic acid was carried out by leaving both spiked samples and the unspiked sample solution in a tightly capped volumetric flask at room temperature for $10 \mathrm{hrs}$ and then in a refrigerator for $48 \mathrm{hrs}$. Content impurity was determined at every two hr interval, up to the study period. Mobile phase stability was also carried out for $48 \mathrm{hrs}$ by injecting the freshly prepared sample solutions at every six hr interval. Esomeprazole-related impurities and the salicylic acid impurity were checked in the test solutions. The mobile phase preparation was kept constant during the study period.

\section{Results and Discussion}

\section{Method Development and Optimization}

The main complexity of the present research work was to develop a stability-indicating method for the estimation of Esomeprazole in low-dose aspirin and esomeprazole pharmaceutical dosage forms in the presence of aspirin. Challenges were observed in the selection of the stationary phase and mobile phase due to the migration of an impurity that was observed in esomeprazole as salicylic acid, produced from aspirin in the capsules of low-dose aspirin and esomeprazole. The main target of the chromatographic method was to get the separation of critically close eluting degradable peaks from main peak and to know the effect of salicylic acid that was produced in the sample preparation and its interference with esomeprazole. Impurities were co-eluted by using different stationary phases like C18, phenyl, and cyano, and different mobile phases containing buffers like phosphate, sulphate, and acetate with different pH's (7-9), and using organic modifiers like acetonitrile, methanol, and ethanol in the mobile phase. After several scientific trials and optimization of the stationary phase, column temperature, flow rate, mobile phase, and $\mathrm{pH}$, the chromatographic separation was achieved on the X-Terra RP-8 $150 \times 4.6 \mathrm{~mm}$ $3.5 \mu \mathrm{m}$ column. The X-terra RP8 column has good selectivity and ruggedness in higher pH's. A $3.5 \mu$ submicron column gave better separation between the seven impurities of esomeprazole, with proper retention and peak shape of the salicylic acid in higher $\mathrm{pH}$ buffer conditions. The gradient LC method consisted of a buffer as mobile phase-A, acetonitrile, and methanol in the ratio of $85 / 15 \mathrm{v} / \mathrm{v}$ as mobile phase- $\mathrm{B}$. The buffer solution contained $6 \mathrm{gms}$ of glycine in 1 liter of Milli-Q water, pH-adjusted to $9.0 \pm 0.1$ with a $50 \%$ sodium hydroxide solution (buffer). The glycine buffer gave better selectivity and robust mobile phase stability at a higher $\mathrm{pH}$, with a sodium borate and EDTA combination providing a basic environment to protect against further degradation of the esomeprazole in the presence of the salicylic acid produced from aspirin in the capsules.

The flow rate of the mobile phase was $1.0 \mathrm{ml} / \mathrm{min}$. gradient programme Time $/ \% \mathrm{v}$ mobile phase-B 0.001/06,12/12,17/18,17.5/20,30/40,40/46,43/85,45/06,50/06. The temperature of the column was maintained at $30^{\circ} \mathrm{C}$ and the detection was monitored at a wavelength of $305 \mathrm{~nm}$. The injection volume was $20 \mu \mathrm{l}$. The diluents used as the buffer $[7.6 \mathrm{~g}$ of disodium tetraborate and $1.0 \mathrm{~g}$ of edetate disodium in 1 liter of Milli-Q water pH-adjusted to $11.0 \pm$ 
0.1 with $50 \%$ sodium hydroxide solution]:ethanol in the ratio of $(80: 20)]$. The concentration was $0.2 \mathrm{mg} \cdot \mathrm{mL}^{-1}$ for the related impurities method. The peak shape of esomeprazole was found to be symmetrical. In the optimized conditions esomeprazole, its related impurities, and the salicylic acid impurity were well-separated with a resolution of greater than 2.5.

Tab. 1. System suitability Report

\begin{tabular}{|c|c|c|}
\hline System suitability parameters & Observed value & Acceptance limit \\
\hline \multicolumn{3}{|c|}{ From System suitability solution } \\
\hline $\begin{array}{l}\text { The resolution between Impurity-B } \\
\text { (Desmethoxy impurity) and Esomeprazole } \\
\text { peaks. }\end{array}$ & 2.8 & NLT 1.5 \\
\hline \multicolumn{3}{|c|}{ From Standard preparation } \\
\hline $\begin{array}{l}\text { The ratio for the Esomeprazole peak } \\
\text { areas of two standard injections }\end{array}$ & 1.0 & Between 0.9 to 1.1 \\
\hline $\begin{array}{l}\text { The ratio for the Salicylic acid peak areas } \\
\text { of two standard injections }\end{array}$ & 1.0 & Between 0.9 to 1.1 \\
\hline $\begin{array}{l}\text { The Tailing factor for Esomeprazole peak } \\
\text { in Standard }\end{array}$ & 1.0 & NMT 2.0 \\
\hline $\begin{array}{l}\text { The Tailing factor for Salicylic acid peak } \\
\text { in Standard }\end{array}$ & 1.0 & NMT 2.0 \\
\hline
\end{tabular}

Tab. 2. Summary of Forced Degradation Study

\begin{tabular}{|c|c|c|c|c|}
\hline \multirow[b]{2}{*}{ Stress Condition } & \multicolumn{4}{|c|}{ Drug Product } \\
\hline & $\begin{array}{l}\text { \% degra- } \\
\text { dation }\end{array}$ & $\begin{array}{l}\text { Purity } \\
\text { angle }\end{array}$ & $\begin{array}{l}\text { Purity } \\
\text { threshold }\end{array}$ & $\begin{array}{l}\text { Purity } \\
\text { flag }\end{array}$ \\
\hline $\begin{array}{l}\text { Refluxed with } 10 \mathrm{~mL} \text { of } 0.1 \mathrm{~N} \mathrm{HCl} \text { solution } \\
\text { for about } 2 \mathrm{hrs} \text { at } 60^{\circ} \mathrm{C} \text { and neutralized with } \\
0.1 \mathrm{~N} \mathrm{NaOH}\end{array}$ & 1.58 & 0.164 & 0.305 & No \\
\hline $\begin{array}{l}\text { Refluxed with } 10 \mathrm{~mL} \text { of } 0.1 \mathrm{~N} \mathrm{NaOH} \text { solution } \\
\text { for about } 2 \text { hrs at } 60^{\circ} \mathrm{C} \text { and neutralized with } \\
0.1 \mathrm{~N} \mathrm{HCl}\end{array}$ & 2.28 & 0.156 & 0.294 & No \\
\hline $\begin{array}{l}\text { Treated with } 5 \mathrm{~mL} \text { of } 3 \% \text { Hydrogen peroxide } \\
\left(\mathrm{H}_{2} \mathrm{O}_{2}\right) \text { for about } 2 \mathrm{hrs} \text { at room temperature }\end{array}$ & 3.68 & 0.166 & 0.422 & No \\
\hline $\begin{array}{l}\text { Refluxed with purified water for about } 2 \mathrm{hrs} \\
\text { at } 60^{\circ} \mathrm{C}\end{array}$ & 1.72 & 0.161 & 0.302 & No \\
\hline $\begin{array}{l}\text { Exposed to Sunlight for about } \\
\text { 1.2 Million Lux hours. }\end{array}$ & 0.55 & 0.151 & 0.484 & No \\
\hline $\begin{array}{l}\text { Exposed to UV light both at shorter and } \\
\text { longer wavelengths for about } 200 \text { watt hours } \\
\text { / square meter. }\end{array}$ & 1.32 & 0.175 & 0.460 & No \\
\hline Dry heating done at $105^{\circ} \mathrm{C}$ for about $2.5 \mathrm{hrs}$. & 10.41 & 0.178 & 0.315 & No \\
\hline $\begin{array}{l}\text { Exposed to humidity at } 25^{\circ} \mathrm{C} \\
90 \% \mathrm{RH} \text { for about } 8 \text { days }\end{array}$ & 0.04 & 0.183 & 0.444 & No \\
\hline
\end{tabular}


The relative response factor for all of the mentioned impurities against the esomeprazole was established. Results are given in Table 6 , the system suitability results are given in Table 1, the developed HPLC method was found to be specific for esomeprazole, its impurities, and salicylic acid. Figure 2, Figure 3, and Figure 4 show the chromatograms of the diluent, impurity blend solution, and the test sample solution.

Tab. 3. Accuracy Data of Esomeprazole and its impurities

\begin{tabular}{|c|c|c|c|c|c|c|c|}
\hline \multicolumn{4}{|c|}{ Impurity-A (Benzimidazole impurity) } & \multicolumn{4}{|c|}{ Impurity-C (Sulphide impurity) } \\
\hline $20 \%$ & 0.4151 & 0.4237 & 102.07 & $20 \%$ & 0.4092 & 0.38503 & 94.07 \\
\hline $40 \%$ & 0.8303 & 0.83257 & 100.27 & $40 \%$ & 0.8183 & 0.8147 & 99.57 \\
\hline $100 \%$ & 2.0757 & 2.23443 & 107.63 & $100 \%$ & 2.0458 & 2.02453 & 99.80 \\
\hline $125 \%$ & 2.5946 & 2.9421 & 113.40 & $125 \%$ & 2.5573 & 2.51397 & 98.30 \\
\hline $150 \%$ & 3.1135 & 3.4253 & 110.00 & $150 \%$ & 3.0688 & 3.0063 & 97.90 \\
\hline \multicolumn{4}{|c|}{ Impurity-B (Desmethoxy impurity) } & \multicolumn{4}{|c|}{ Impurity-D (Sulphone impurity) } \\
\hline $20 \%$ & 0.3882 & 0.42667 & 109.87 & $20 \%$ & 0.4011 & 0.41477 & 103.40 \\
\hline $40 \%$ & 0.7765 & 0.8162 & 105.13 & $40 \%$ & 0.8023 & 0.81767 & 101.90 \\
\hline $100 \%$ & 1.9412 & 1.9817 & 102.10 & $100 \%$ & 2.0037 & 1.93713 & 96.57 \\
\hline $125 \%$ & 2.4265 & 2.4069 & 99.20 & $125 \%$ & 2.5071 & 2.46487 & 98.33 \\
\hline $150 \%$ & 2.9118 & 2.93317 & 100.73 & $150 \%$ & 3.0688 & 2.92577 & 97.90 \\
\hline \multicolumn{4}{|c|}{ Impurity-E (N-Oxide impurity) } & \multicolumn{4}{|c|}{ Impurity-F (N-methyl impurity) } \\
\hline $20 \%$ & 0.4262 & 0.47127 & 110.23 & $20 \%$ & 0.4232 & 0.4103 & 96.97 \\
\hline $40 \%$ & 0.8565 & 0.84143 & 98.23 & $40 \%$ & 0.8465 & 0.8563 & 101.17 \\
\hline $100 \%$ & 2.1412 & 2.06797 & 96.60 & $100 \%$ & 2.1161 & 2.12 & 100.20 \\
\hline $125 \%$ & 2.6765 & 2.58827 & 96.70 & $125 \%$ & 2.6452 & 2.64627 & 100.03 \\
\hline $150 \%$ & 3.2118 & 3.09077 & 96.23 & $150 \%$ & 3.1742 & 3.1815 & 100.23 \\
\hline \multicolumn{4}{|c|}{ Impurity-G (Dihydropyridine imp.) } & \multicolumn{4}{|c|}{ Salicylic acid impurity } \\
\hline $20 \%$ & 0.4029 & 0.4118 & 102.20 & $20 \%$ & 2.5171 & 2.69533 & 107.07 \\
\hline $40 \%$ & 0.8058 & 0.8147 & 101.10 & $40 \%$ & 5.0343 & 5.5512 & 110.27 \\
\hline $100 \%$ & 2.0146 & 2.14973 & 106.73 & $100 \%$ & 12.0823 & 12.6783 & 104.93 \\
\hline $125 \%$ & 2.5183 & 2.50357 & 99.43 & $125 \%$ & 15.1028 & 15.6488 & 103.60 \\
\hline $150 \%$ & 3.0219 & 3.06847 & 101.50 & $150 \%$ & 18.1234 & 19.1186 & 105.47 \\
\hline \multicolumn{4}{|c|}{ Esomeprazole Impurity } & & & & \\
\hline $20 \%$ & 0.1652 & 0.16653 & 100.80 & & & & \\
\hline $40 \%$ & 0.3303 & 0.34637 & 104.90 & & & & \\
\hline $100 \%$ & 0.8114 & 0.87267 & 107.57 & & & & \\
\hline $125 \%$ & 1.0142 & 1.08993 & 107.47 & & & & \\
\hline $150 \%$ & 1.2171 & 1.3484 & 110.80 & & & & \\
\hline
\end{tabular}

\section{Results of Forced Degradation Studies}

The drug was exposed to $0.1 \mathrm{~N} \mathrm{HCl}$ at $60^{\circ} \mathrm{C}$ for $120 \mathrm{~min}$. Esomeprazole has shown significant sensitivity towards the treatment of $0.1 \mathrm{~N} \mathrm{HCl}$. The drug gradually underwent degradation with time in $0.1 \mathrm{~N} \mathrm{HCl}$ and prominent degradation was observed $(\sim 2 \%)$. The representative chromatogram is presented in Figure 5.

Degradation in Basic Solution 
The drug was exposed to $0.1 \mathrm{~N} \mathrm{NaOH}$ at $60^{\circ} \mathrm{C}$ for $120 \mathrm{~min}$. Esomeprazole has shown mild sensitivity towards the treatment of $0.1 \mathrm{~N} \mathrm{NaOH}$. The drug gradually underwent degradation with time in $0.1 \mathrm{~N} \mathrm{NaOH}$ and degradation was observed $(\sim 2.5 \%)$. The representative chromatogram is presented in Figure 6.

Tab. 4. Precision Data of Esomeprazole and its impurities

\begin{tabular}{|c|c|c|c|c|c|c|c|c|}
\hline \multirow{3}{*}{$\begin{array}{l}\text { Sample } \\
\text { No. }\end{array}$} & \multicolumn{8}{|c|}{ Esomeprazole Magnesium Impurities } \\
\hline & \multicolumn{2}{|c|}{$\begin{array}{c}\text { Impurity-A } \\
\text { (Benzimidazole } \\
\text { impurity) }\end{array}$} & \multicolumn{2}{|c|}{$\begin{array}{c}\text { Impurity-B } \\
\text { (Desmethoxy } \\
\text { impurity) }\end{array}$} & \multicolumn{2}{|c|}{$\begin{array}{l}\text { Impurity-C } \\
\text { (Sulphide } \\
\text { impurity) }\end{array}$} & \multicolumn{2}{|c|}{$\begin{array}{l}\text { Impurity-D } \\
\text { (Sulphone } \\
\text { impurity) }\end{array}$} \\
\hline & RRT & $\%$ Imp. & RRT & $\%$ Imp. & RRT & \% Imp. & RRT & $\%$ Imp. \\
\hline 1 & 0.61 & 0.456 & 0.97 & 0.457 & 1.31 & 0.475 & 0.84 & 0.486 \\
\hline 2 & 0.61 & 0.456 & 0.97 & 0.459 & 1.31 & 0.477 & 0.84 & 0.483 \\
\hline 3 & 0.61 & 0.453 & 0.97 & 0.46 & 1.31 & 0.47 & 0.84 & 0.486 \\
\hline 4 & 0.61 & 0.454 & 0.97 & 0.458 & 1.31 & 0.48 & 0.84 & 0.485 \\
\hline 5 & 0.61 & 0.449 & 0.97 & 0.458 & 1.31 & 0.473 & 0.84 & 0.483 \\
\hline 6 & 0.61 & 0.45 & 0.97 & 0.461 & 1.31 & 0.477 & 0.84 & 0.486 \\
\hline AVG & - & 0.453 & - & 0.459 & - & 0.475 & - & 0.485 \\
\hline \multirow[t]{4}{*}{$\%$ RSD } & - & 0.7 & - & 0.3 & - & 0.7 & - & 0.3 \\
\hline & \multicolumn{6}{|c|}{ Esomeprazole Magnesium Impurities } & & \\
\hline & \multicolumn{2}{|c|}{$\begin{array}{l}\text { Impurity-E } \\
\text { (N-Oxide } \\
\text { impurity) }\end{array}$} & \multicolumn{2}{|c|}{$\begin{array}{c}\text { Impurity-F } \\
\text { (N-Methyl } \\
\text { impurity) }\end{array}$} & \multicolumn{2}{|c|}{$\begin{array}{c}\text { Impurity-G } \\
\text { (Dihydropyridine } \\
\text { impurity) }\end{array}$} & \multicolumn{2}{|c|}{$\begin{array}{l}\text { Salicylic acid } \\
\text { impurity }\end{array}$} \\
\hline & RRT & $\%$ Imp. & RRT & \% Imp. & RRT & $\%$ Imp. & RRT & \% Imp. \\
\hline 1 & 0.74 & 0.464 & 1.09 & 0.492 & 0.26 & 0.471 & 0.13 & 0.27 \\
\hline 2 & 0.74 & 0.46 & 1.09 & 0.491 & 0.26 & 0.469 & 0.13 & 0.263 \\
\hline 3 & 0.74 & 0.458 & 1.09 & 0.489 & 0.26 & 0.464 & 0.13 & 0.268 \\
\hline 4 & 0.74 & 0.462 & 1.09 & 0.495 & 0.26 & 0.472 & 0.13 & 0.271 \\
\hline 5 & 0.74 & 0.46 & 1.1 & 0.489 & 0.26 & 0.468 & 0.13 & 0.27 \\
\hline 6 & 0.74 & 0.459 & 1.1 & 0.489 & 0.26 & 0.472 & 0.13 & 0.266 \\
\hline AVG & - & 0.461 & - & 0.491 & - & 0.469 & - & 0.268 \\
\hline$\%$ RSD & - & 0.5 & - & 0.5 & - & 0.7 & - & 1.1 \\
\hline
\end{tabular}

\section{Oxidative Conditions}

The drug was exposed to $3 \%$ hydrogen peroxide at room temperature for $120 \mathrm{~min}$. Esomeprazole has shown no significant sensitivity towards the treatment of $3 \%$ hydrogen peroxide and the drug showed mild sensitivity in oxidative conditions ( $4 \%)$. Esomeprazole has shown mild degradation under forced photo and sunlight degradation. From the degradation studies, the peak purity test results derived from the PDA detector confirmed that the esomeprazole peak was homogeneous and pure in all the analyzed stress samples. The mass balance of the stressed samples was close to $99.5 \%$. After exposing esomeprazole to sunlight (1.2 million Lux hours) and UV light (200 wt hours per sq meter), 0.55 and $1.32 \%$ degradation was observed. After dry heating at $105^{\circ} \mathrm{C}$ for 2 hours it was exposed to humidity at $25^{\circ} \mathrm{C} / 90 \% \mathrm{RH}$ for about 7 days. The forced degradation study results are given in Table 2 . The representative chromatogram is presented in Fig. 7-9. 
Tab. 5. Limit of Detection and Limit of Quantification of Esomeprazole and its impurities

\begin{tabular}{lcccc}
\hline \multirow{2}{*}{ Name } & \multicolumn{2}{c}{ \% impurity } & \multicolumn{2}{c}{ Signal to Noise Ratio } \\
\cline { 2 - 5 } Impurity-A (Benzimidazole impurity) & LOD & LOQ & LOD & LOQ \\
\cline { 2 - 5 } Impurity-B (Desmethoxy impurity) & 0.003 & 0.009 & 2.7 & 10.4 \\
Impurity-C (Sulphide impurity) & 0.005 & 0.016 & 2.9 & 10.3 \\
Impurity-D (Sulphone impurity) & 0.01 & 0.023 & 3 & 10.2 \\
Impurity-E (N-Oxide impurity) & 0.008 & 0.016 & 2.7 & 9.6 \\
Impurity-F (N-Methyl impurity) & 0.007 & 0.027 & 3 & 10.2 \\
Impurity-G (Dihydropyridine impurity) & 0.01 & 0.029 & 3 & 10.1 \\
Salicylic acid impurity & 0.004 & 0.012 & 3.2 & 10.2 \\
Esomeprazole Magnesium & 0.006 & 0.004 & 3.3 & 9.5 \\
\hline
\end{tabular}

Tab. 6. Linearity

\begin{tabular}{lcc}
\hline Name & $\begin{array}{c}\text { Coefficient of } \\
\text { correlation (r) }\end{array}$ & $\begin{array}{c}\text { Relative } \\
\text { response factor }\end{array}$ \\
\hline Impurity-A (Benzimidazole impurity) & 0.998 & 2.85 \\
Impurity-B (Desmethoxy impurity) & 0.998 & 1.10 \\
Impurity-C (Sulphide impurity) & 0.997 & 1.05 \\
Impurity-D (Sulphone impurity) & 0.998 & 0.94 \\
Impurity-E (N-Oxide impurity) & 0.998 & 0.93 \\
Impurity-F (N-Methyl impurity) & 0.998 & 0.81 \\
Impurity-G (Dihydropyridine impurity) & 0.998 & 1.47 \\
Salicylic acid impurity & 0.999 & 1.00 \\
Esomeprazole Magnesium & 0.999 & 1.00 \\
\hline
\end{tabular}

Tab. 7. Linearity and Range at LOQ level

\begin{tabular}{lcc}
\hline Name & Spike level & Mean \% Recovery \\
\hline \multirow{2}{*}{ Impurity-A (Benzimidazole impurity) } & At LOQ & 91.8 \\
& At 150\% & 109.9 \\
Impurity-B (Desmethoxy impurity) & At LOQ & 105.3 \\
& At 150\% & 100.6 \\
Impurity-C (Sulphide impurity) & At LOQ & 109.0 \\
& At 150\% & 97.6 \\
Impurity-C (Sulphone impurity) & At LOQ & 105.0 \\
& At 150\% & 97.6 \\
Impurity-E (N-Oxide impurity & At LOQ & 97.5 \\
& At 150\% & 96.3 \\
Impurity-F (N-Methyl impurity) & At LOQ & 102.8 \\
& At 150\% & 99.9 \\
Impurity-G (Dihydropyridine impurity) & At LOQ & 106.7 \\
& At 150\% & 101.7 \\
Salicylic acid impurity & At LOQ & 101.6 \\
& At 150\% & 105.6 \\
Esomeprazole magnesium & At LOQ & 101.7 \\
& At 150\% & 110.1 \\
\hline
\end{tabular}




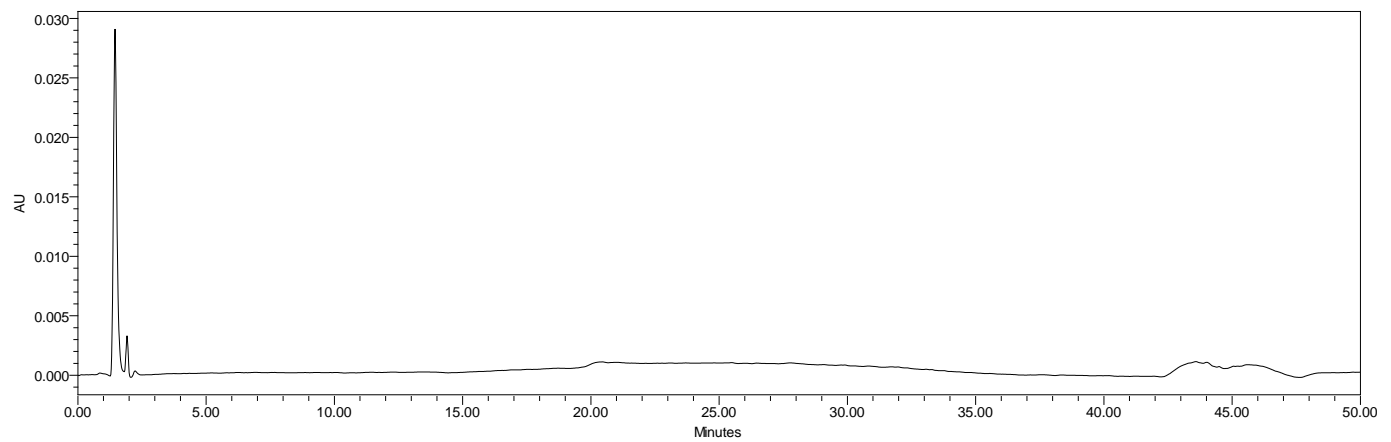

Fig. 2. Typical HPLC Chromatogram of Diluent

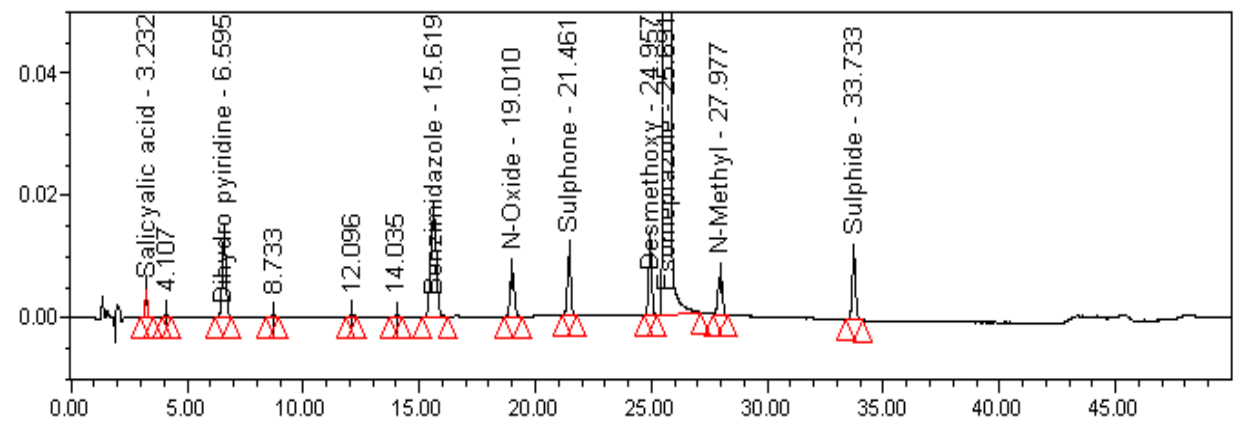

Fig. 3. Typical HPLC Chromatogram of Impurities Blend Solution

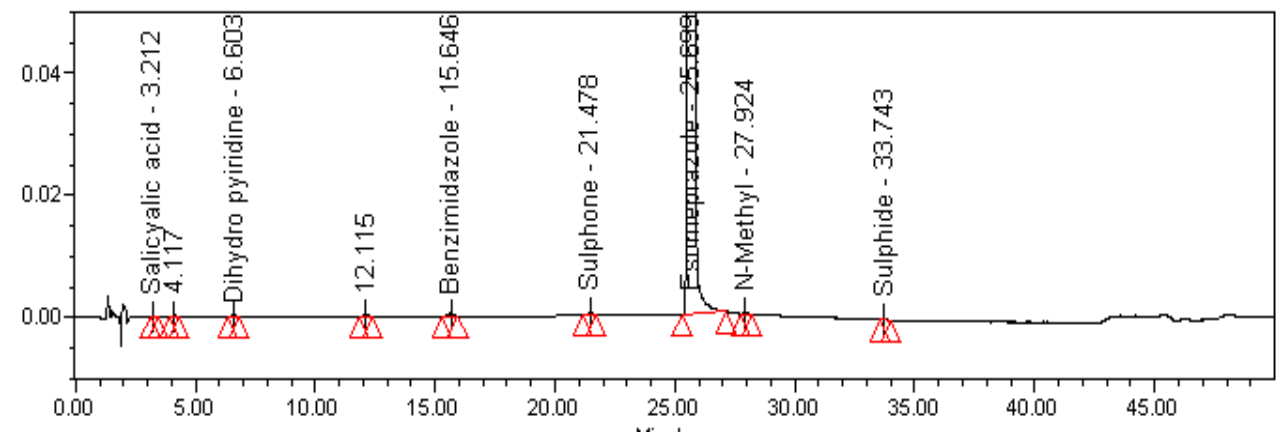

Fig. 4. Typical HPLC Chromatogram of Sample

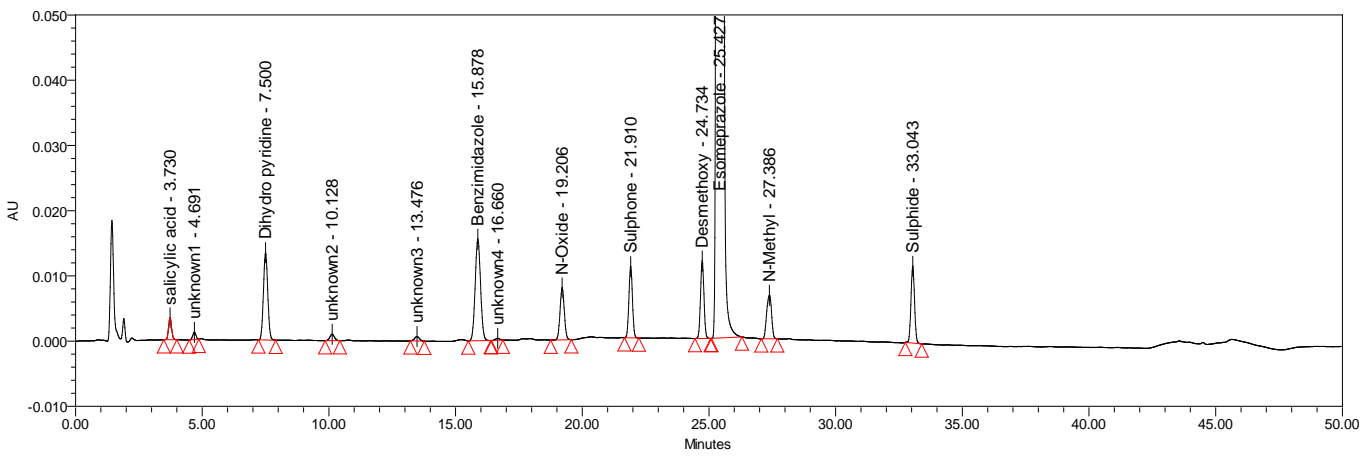

Fig. 5. Typical HPLC Chromatogram of Acid Degradation 


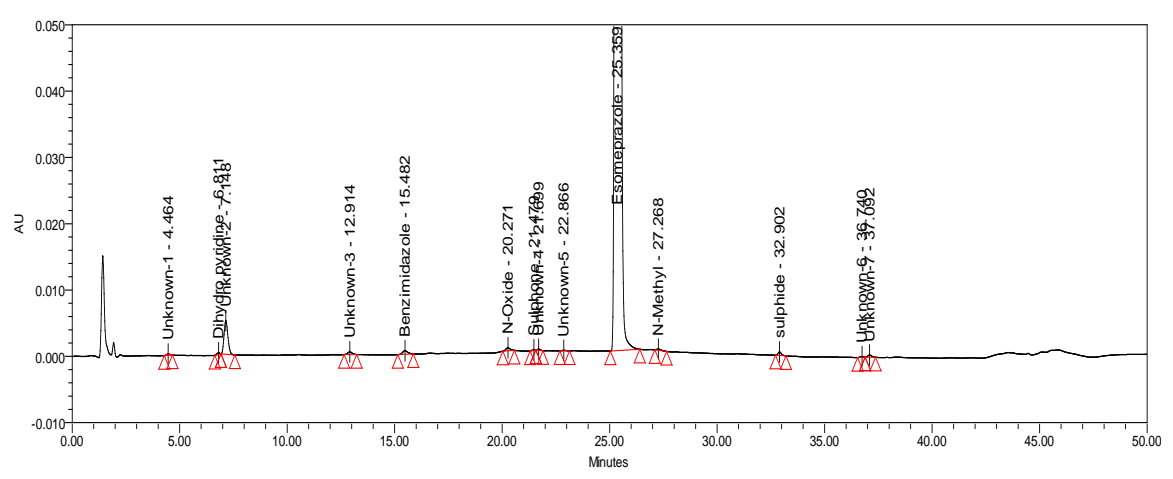

Fig. 6. Typical HPLC Chromatogram of Base Degradation

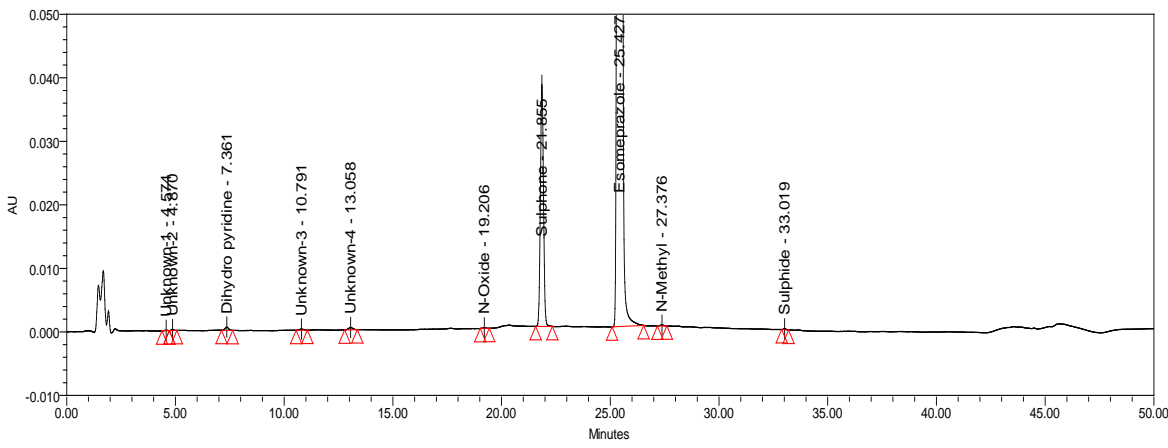

Fig. 7. Typical HPLC Chromatogram of Oxidation Degradation

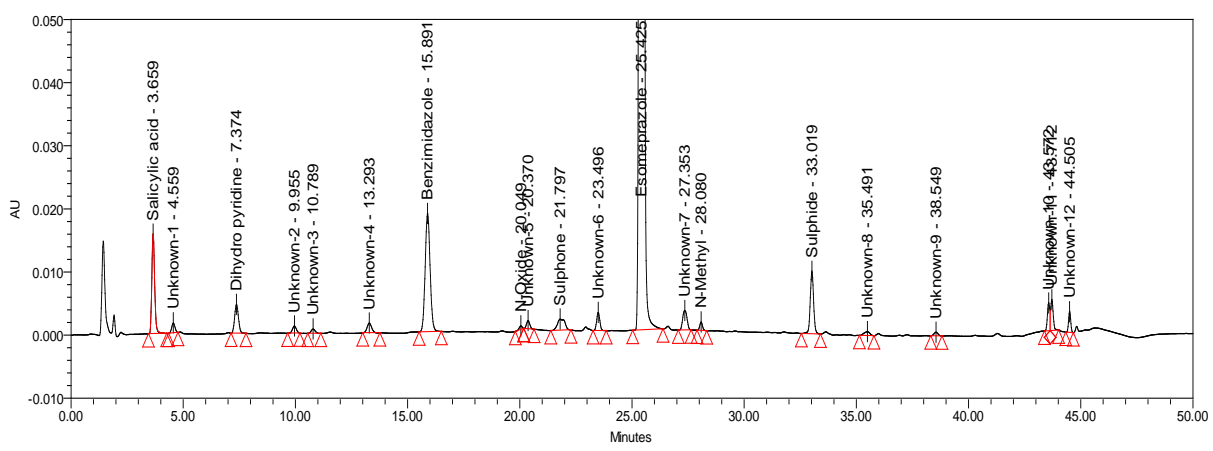

Fig. 8. Typical HPLC Chromatogram Thermal Degradation

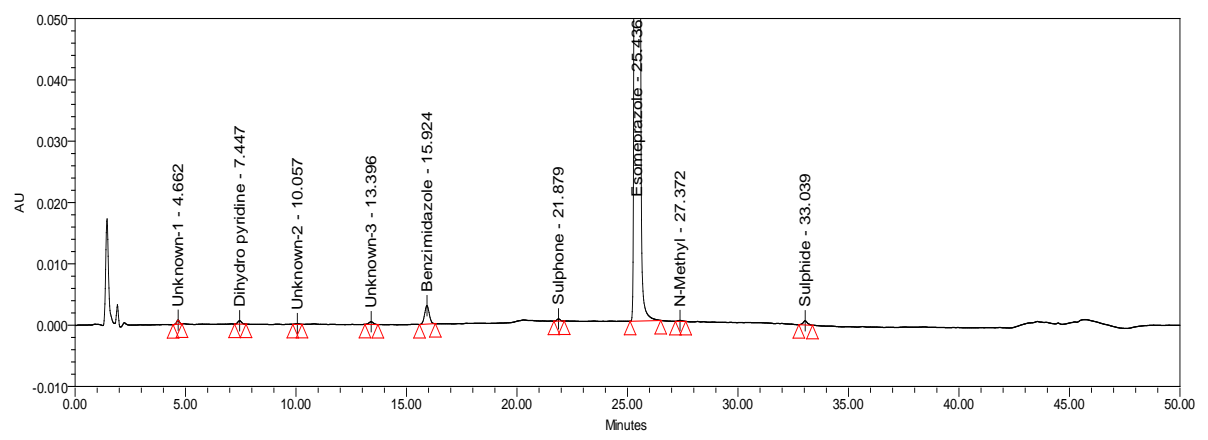

Fig. 9. Typical HPLC Chromatogram of Sunlight Stressed Degradation 


\section{Method validation}

\section{Accuracy}

The test method was found to be accurate from the limit of quantification level to $150 \%$ of the target concentration (the target concentration is $0.5 \%$ for all of the esomeprazole impurities, for salicylic acid $0.30 \%$, and esomeprazole of the target concentration $0.2 \%$ of the level of unknown impurities (on placebo)). The \% individual recovery at all of the spike levels of all impurities and esomeprazole was found to be within the limit. The results are summarized in Table 3.

\section{Precision}

The precision of the test method by injecting six samples was prepared by spiking the test preparation with the esomeprazole impurities blend solution to get Impurity-A (Benzimidazole impurity), Impurity-B (Desmethoxy impurity), Impurity-C (Sulphide impurity), Impurity-D (Sulphone impurity), Impurity-E (N-Oxide impurity), Impurity-F (N-Methyl impurity), Impurity-G (Dihydropyridine impurity) at $0.50 \%$ and salicylic acid at $0.3 \%$. The relative standard deviation of $\%$ impurities were calculated. The experimental data is represented in Table 4.

\section{Sensitivity}

The limit of detection of esomeprazole and its related impurities, and salicylic acid (of analyte concentration, i.e. $0.2 \mathrm{mg} / \mathrm{ml}$ ) was a $20 \mu \mathrm{l}$ injection volume. The limit of quantification of esomeprazole and its related impurities, and salicylic acid (of analyte concentration, i.e. $0.2 \mathrm{mg} / \mathrm{mL}$ ) was a $20 \mu \mathrm{l}$ injection volume. The precision at the LOQ concentration were below $10 \%$. Experimental data is shown in Table 5.

\section{Linearity and Range}

The linearity was established by plotting a graph between the concentration versus peak area response of the esomeprazole and its impurities, and the salicylic acid impurity. A series of solutions of esomeprazole and its impurities with concentrations ranging from the limit of quantification level to $200 \%$ of the target concentration $(0.5 \%)$ were prepared and injected into the HPLC system.

The detector response was found to be linear with a correlation coefficient of at least 0.997 for all esomeprazole impurities and the esomeprazole peak. The results and linearity graphs are summarized in Table 5, Table 6, Table 7, and Figure 10.

\section{Robustness}

Close observation of analysis results for the deliberately changed chromatographic conditions (flow rate, $\mathrm{pH}$, and column temperature) revealed that the resolution between closely eluting peaks, namely esomeprazole and its related impurity, was always greater than 2.5, illustrating the robustness of the method.

\section{Solution Stability and Mobile Phase Stability}

No significant changes were observed in the content of esomeprazole and its related impurities, and the salicylic acid impurity during the solution stability and mobile phase stability experiments for the related impurities. The \%RSD of impurities of esomeprazole 
during the solution stability and mobile phase stability experiments was within $0.02 \%$. The solution stability and mobile phase stability experiment data confirm that the sample solutions and mobile phase used during related impurities determination were stable up to the study period of 10 hours at the benchtop and 48 hours in the refrigerator.

\section{Related substance Analysis}

An analysis was performed for the different batches of esomeprazole in the low-dose aspin and esomeprazole dosage forms in $(n=3)$ impurities ranging from $0.05 \%-0.16 \%$.

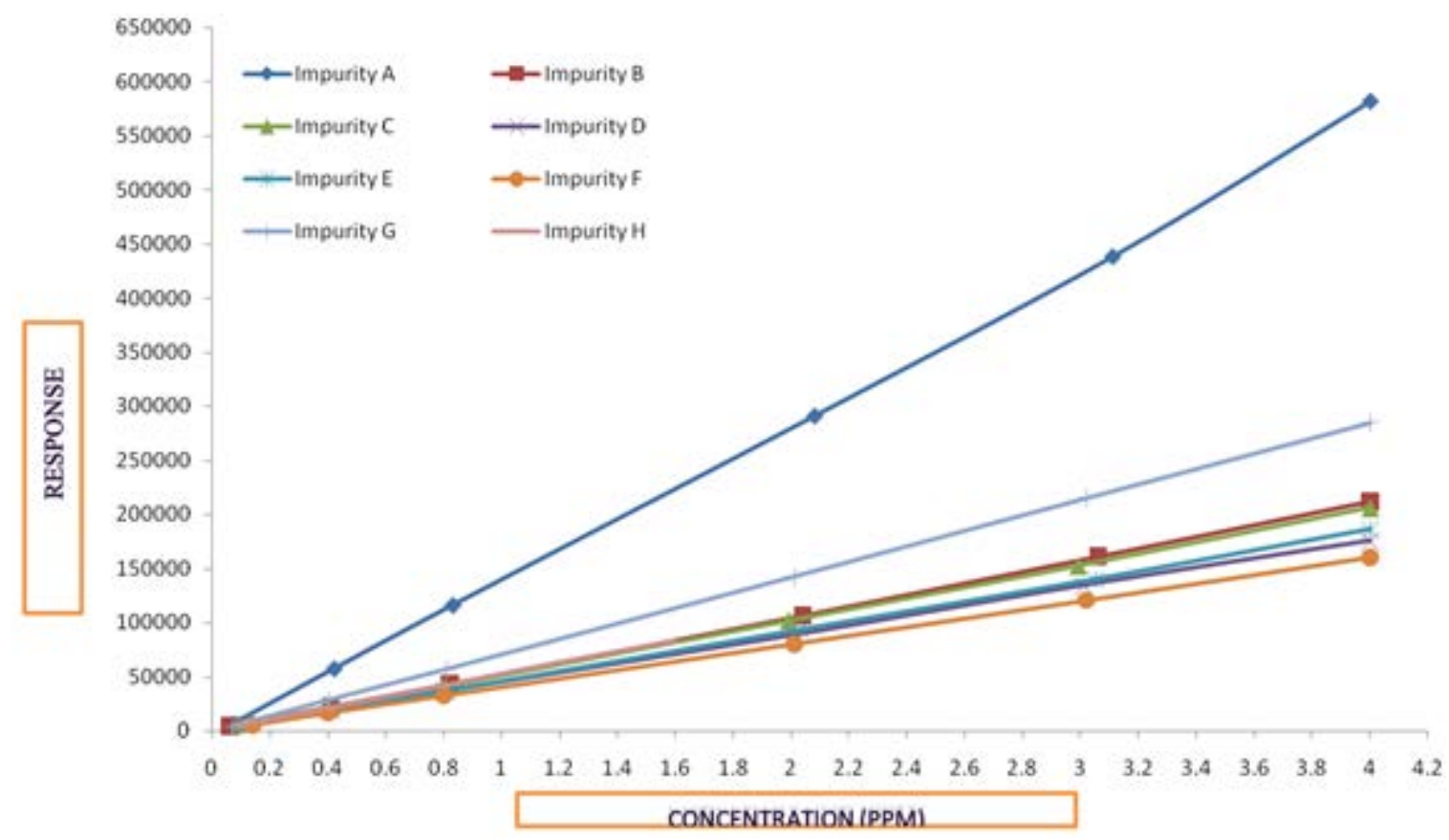

Fig. 10. Linearity plot of Esomeprazole and its Related impurities

\section{Conclusion}

In this present research article, the complete degradation stress study reported for esomeprazole and its related impurities in presence of aspirin. The RP-HPLC method developed for the related impurities was linear, precise, accurate, and specific. The method was completely validated showing satisfactory data for all of the method validation parameters tested as per ICH guidelines. The developed method is stability-indicating and can be used for the routine analysis of production samples and to check the stability of esomeprazole. To the best of our knowledge, the specified method presented in the article successfully measures esomeprazole and its related impurities, and the migration impurity salicylic acid (aspirin degradant).

\section{Acknowledgement}

We wish to express our sincere thanks to the Management of Dr. Reddys Laboratories, Hyderabad, India for their support and encouragement. Cooperation from colleagues and of Research \& Development and Analytical Research \& Development of Dr. Reddy's Laboratories Ltd. is appreciated. 


\section{Authors' Statement}

\section{Competing Interests}

The authors declare no conflict of interest.

\section{References}

[1] Hassan-Alin M, Andersson T, Bredberg E, Röhss K.

Pharmacokinetics of esomeprazole after oral and intravenous administration of single and repeated doses to healthy subjects.

Eur J Clin Pharmacol. 2000; 56: 665-670.

http://dx.doi.org/10.1007/s002280000206

[2] Andersson T, Hassan-Alin M, Hasselgren G, Röhss K, Weidolf L.

Pharmacokinetic studies with esomeprazole, the (S)-isomer of omeprazole.

Clin Pharmacokinet. 2001; 40: 411-426.

http://dx.doi.org/10.2165/00003088-200140060-00003

[3] Andersson T.

Pharmacokinetics, metabolism and interactions of acid pump inhibitors. Focus on omeprazole, lansoprazole and pantoprazole.

Clin Pharmacokin. 1996; 31: 9-28.

http://dx.doi.org/10.2165/00003088-199631010-00002

[4] Lind T, Rydberg L, Kylbäck A, Andersson T, Hasselgren G, Holmberg J, Röhss K.

Esomeprazole provides improved acid control vs. omeprazole In patients with symptoms of gastrooesophageal reflux disease.

Aliment Pharmacol Ther. 2000; 14: 861-867.

http://dx.doi.org/10.1046/j.1365-2036.2000.00813.x

[5] Richter JE, Kahrilas PJ, Johanson J, Maton P, Breiter JR, Hwang C, Marino V, Hamelin B, Levine JG; Esomeprazole Study Investigators.

Efficacy and safety of esomeprazole compared with omeprazole in GERD patients with erosive esophagitis: a randomized controlled trial.

Am J Gastroenterol. 200; 96: 656-665.

http://dx.doi.org/10.1111/j.1572-0241.2001.3600_b.x

[6] Röhss K, Hasselgren G, Hedenström H.

Effect of esomeprazole $40 \mathrm{mg}$ vs omeprazole $40 \mathrm{mg}$ on 24-hour intragastric $\mathrm{pH}$ in patients with symptoms of gastroesophageal reflux disease.

Dig Dis Sci. 2002; 47: 954-958.

http://dx.doi.org/10.1023/A:1015009300955

[7] Benedek IH, Joshi AS, Pieniaszek HJ, King SP and Kornhauser DM.

Variability in the pharmacokinetics and pharmacodynamics of low-dose aspirin in healthy male volunteers.

J Clin Pharmacol.1995; 35: 1181-1186.

http://dx.doi.org/10.1002/j.1552-4604.1995.tb04044.x

[8] Krumholz HM, Radford MJ, Ellerbeck EF, Hennen J, Meehan TP, Petrillo M, Wang Y, Kresowik TF, Jencks SF.

Aspirin in the Treatment of Acute Myocardial Infarction in Elderly Medicare Beneficiaries: Patterns of Use and Outcomes.

Circulation. 1995; 92: 2841-2847.

http://dx.doi.org/10.1161/01.CIR.92.10.2841 
[9] Lewis HD Jr, Davis JW, Archibald DG, Steinke WE, Smitherman TC, Doherty JE 3rd, Schnaper HW, LeWinter MM, Linares E, Pouget JM, Sabharwal SC, Chesler E, DeMots H.

Protective effects of aspirin against acute myocardial infarction and death in men with unstable angina. Results of a Veterans Administration Cooperative Study.

N Engl J Med.1983; 309: 396-403.

http://dx.doi.org/10.1056/NEJM198308183090703

[10] Vijaya Bharathi D, Hotha KK, Kolagatla PR, Venkateswarlu V.

Low dose aspirin estimation: an application to a human pharmacokinetic study.

Biomed Chromatogr. 2013; 27: 589-598.

http://dx.doi.org/10.1002/bmc.2832

[11] Reddy PS, Sait S, Hotha KK,

Extensive Study of Aspirin and Its Related Impurities Under Various Stressed Conditions in Low Dose Aspirin and Esomeprazole Magnesium Capsules.

Am J PharmTech Res. 2012; 2: 848-862.

[12] Reddy PS, Sait S, Vasudevmurthy G, Vishwanath B, Prasad V, Reddy SJ.

Stability indicating simultaneous estimation of assay method for naproxen and esomeprazole in pharmaceutical formulations by RP-HPLC.

Der Pharma Chemica. 2011; 3: 553-564.

[13] Vani P, Kottapalli KS.

Development And Validation of Rp-HPLC Method For Simultaneous estimation of Naproxen And Esomeprazole in Pharmaceutical Dosage Form.

Int J Pharm Technol. 2011; 3: 3446-3455.

[14] Yuen KH, Choy WP, Tan HY, Wong JW, Yap SP.

Improved high performance liquid chromatographic analysis of omeprazole in human plasma.

J Pharm Biomed Anal. 2001; 24: 715-719.

http://dx.doi.org/10.1016/S0731-7085(00)00473-8

[15] Grundevik G. Jerndal, K. Balmer, B.-A. Persson,

Fully automated gradient elution liquid chromatographic assay of omeprazole and two metabolites.

J Pharm Biomed Anal. 1986; 4: 389-398.

http://dx.doi.org/10.1016/0731-7085(86)80060-7

[16] Vittal S, Ganneboina R, Layek B, Trivedi RK, Hotha KK, Bharathi DV, Mullangi R.

Highly sensitive method for the determination of omeprazole in human plasma by liquid chromatography-electrospray ionization tandem mass spectrometry: application to a clinical pharmacokinetic study.

Biomed Chromatogr. 2008; 23: 390-396.

http://dx.doi.org/10.1002/bmc.1129

[17] Bharathi DV, Hotha KK, Jagadeesh B, Chatki PK, Thriveni K, Mullangi R, Naidu A.

Simultaneous estimation of four proton pump inhibitors-lansoprazole, omeprazole, pantoprazole and rabeprazole: development of a novel generic HPLC-UV method and its application to clinical pharmacokinetic study.

Biomed Chromatogr. 2009; 23: 732-739.

http://dx.doi.org/10.1002/bmc.1177

[18] Woolf EJ, Matuszewski BK.

Simultaneous determination of omeprazole and 5'-hydroxyomeprazole in human plasma by liquid chromatography-tandem mass spectrometry.

J Chromatogr A. 1998; 828: 229-238.

http://dx.doi.org/10.1016/S0021-9673(98)00790-0

[19] Kanazawa H, Okada A, Matsushima Y, Yokota H, Okubo S, Mashige F, Nakahara K.

Determination of omeprazole and its metabolites in human plasma by liquid chromatography-mass spectrometry.

J Chromatogr A. 2002; 949: 1-9.

http://dx.doi.org/10.1016/S0021-9673(01)01508-4 
[20] Hoffman U, Schwab M, Treiber G, Klotz U.

Sensitive quantification of omeprazole and its metabolites in human plasma by liquid chromatographymass spectrometry.

J Chromatogr B. 2006; 831: 85-89.

http://dx.doi.org/10.1016/j.jchromb.2005.11.036

[21] Shimizu M, Uno T, Niioka T, Yaui-Furukori N, Takahata T, Sugawara K, Tateishi T.

Sensitive determination of omeprazole and its two main metabolites in human plasma by columnswitching high-performance liquid chromatography: application to pharmacokinetic study in relation to CYP2C19 genotypes.

J Chromatogr B. 2006; 832: 241-248.

http://dx.doi.org/10.1016/j.jchromb.2006.01.022

[22] Oliveira CH, Barrientos-Astigarraga RE, Abib E, Mendes GD, da Silva DR, de Nucci G.

Lansoprazole quantification in human plasma by liquid chromatography-electrospray tandem mass spectrometry.

J Chromatogr B. 2003; 783: 453-459.

http://dx.doi.org/10.1016/S1570-0232(02)00711-0

[23] Wang J, Wang Y, Fawcett JP, Wang Y, Gu J.

Determination of omeprazole in human plasma by liquid chromatography-electrospray quadrupole linear ion trap mass spectrometry.

J Pharm Biomed Anal. 2005; 39: 631-635.

http://dx.doi.org/10.1016/j.jpba.2005.04.011

[24] Stenhoff H, Blomqvist A, Lagerström PO.

Determination of the enantiomers of omeprazole in blood plasma by normal-phase liquid

chromatography and detection by atmospheric pressure ionization tandem mass spectrometry.

J Chromatogr B. 1999; 734: 191-201.

http://dx.doi.org/10.1016/S0378-4347(99)00324-2

[25] Cass QB, Lima VV, Oliveira RV, Cassiano NM, Degani ALG, Pedrazzoli J.

Enantiomeric determination of the plasma levels of omeprazole by direct plasma injection using highperformance liquid chromatography with achiral-chiral column-switching.

J Chromatogr B. 2003; 798: 275-281.

http://dx.doi.org/10.1016/j.jchromb.2003.09.053

[26] Frerichs VA, Zaranek C, Hass CE.

Analysis of omeprazole, midazolam and hydroxy-metabolites in plasma using liquid chromatography coupled to tandem mass spectrometry.

J Chromatogr B. 2005; 824: 71-78.

http://dx.doi.org/10.1016/j.jchromb.2005.07.001

[27] Martens-Lobenhoffer J, Reiche I, Troger U, Monkemuller K, Malfertheiner P, Bode-Boger SM. Enantioselective quantification of omeprazole and its main metabolites in human serum by chiral HPLC-atmospheric pressure photoionization tandem mass spectrometry.

J Chromatogr B. 2007; 857: 301-307.

http://dx.doi.org/10.1016/j.jchromb.2007.07.038

[28] Song O, Naidong W.

Analysis of omeprazole and 5-OH omeprazole in human plasma using hydrophilic interaction chromatography with tandem mass spectrometry (HILIC-MS/MS)--eliminating evaporation and reconstitution steps in 96-well liquid/liquid extraction.

J Chromatogr B. 2002; 830: 135-145.

http://dx.doi.org/10.1016/j.jchromb.2005.10.042,

[29] Hultman la, Stenhoff H, Liljeblad M.

Determination of esomeprazole and its two main metabolites in human, rat and dog plasma by liquid chromatography with tandem mass spectrometry.

J Chromatogr B Analyt Technol Biomed Life Sci. 2007; 848: 317-322.

http://dx.doi.org/10.1016/j.jchromb.2006.10.074 
[30] $\mathrm{ICH}$.

Q2A, Text on validation of analytical procedure (October 1994).

[31] $\mathrm{ICH}$.

Q2B, Analytical Validation - Methodology (November 1996).

[32] $\mathrm{ICH}$.

Q2 (R1), Validation of Analytical Procedures Text and Methodology (November 2005). 